\title{
Trachemys scripta elegans (Testudines: Emydidae) threatens a wetland of international significance in Iran
}

\author{
OMID MOZAFFARI ${ }^{1 *}$, POUYA RAHBARI ${ }^{2} \&$ MOHAMMAD DEHDAR DARGAHI ${ }^{2}$
}

${ }^{1}$ Aria Herpetological Institute, No.1, Parastoo 4 St., Shahrak-e-Homa, Ashrafi-e-Esfehani Highway, Tehran, Iran

${ }^{2}$ Department of Environment, Lahijan branch, Islamic Azad University, Lahijan, Iran

*Corresponding author e-mail: o.mozaffari@gmail.com

$T^{1}$

he freshwater turtle Trachemys scripta elegans (Wied, 1838), commonly called the red eared slider, is native to the Mississippi Valley, USA (Ernst \& Lovich, 2009). Due to the vividly coloured shell of hatchlings the species has been favoured by the pet trade since the 1950s and is now considered to be among the most commonly-traded reptile pets worldwide (Lowe et al., 2000). Consequently, the species may now be encountered as an exotic on five continents (Newberry, 1984; Gasperetti et al., 1993; Chen \& Lue, 1998; Feldman, 2007; Natividad et al., 2008) and in some countries breeding has been confirmed.

The red eared slider has been observed by ourselves and other researchers in six water bodies in northern Iran, close to the Caspian Sea (Table 1, Fig. 1). All our own observations of the species were made by naked eye or with $6 \times 30$ vixen binoculars. The first sighting was of a sub-adult male in 2002 in Amir-kabir reservoir, followed in 2005 by a specimen sunning itself on the bank of Sefidrud reservoir. In 2012, a group of 20 individuals ( 12 males and eight females) were observed basking on the shoreline of Shoormast Lake (Moradi \& Rastegar-Pouyani, 2015). Safaei et al. (2015) reported a single specimen in the Mamloo reservoir and in 2017 we observed a group of more than 40 individuals in Eynak wetland. Then in 2018, we observed three specimens in the Anzali wetland (a Ramsar site - wetland of international importance), two of which were basking alongside two native pond turtle species (Fig. 2).

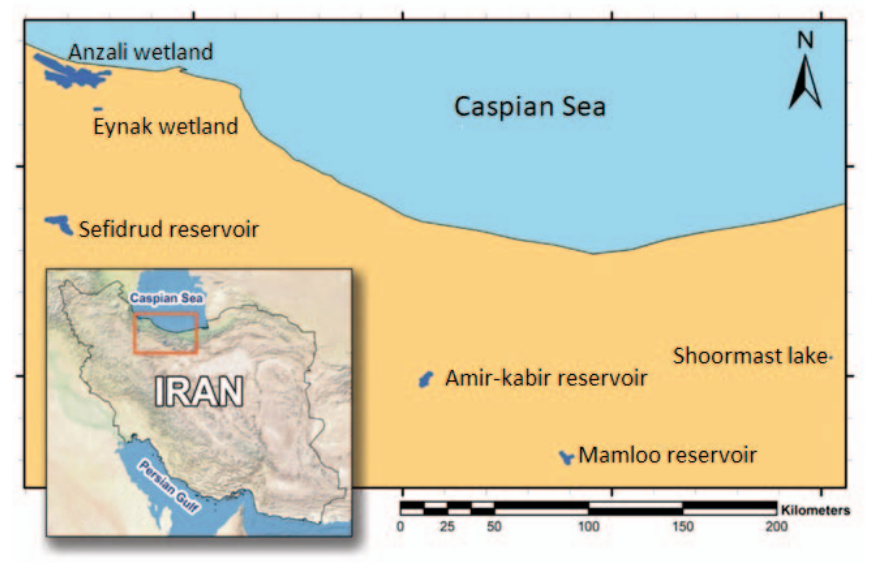

Figure 1. Map of all known sites of T. scripta elegens in Iran

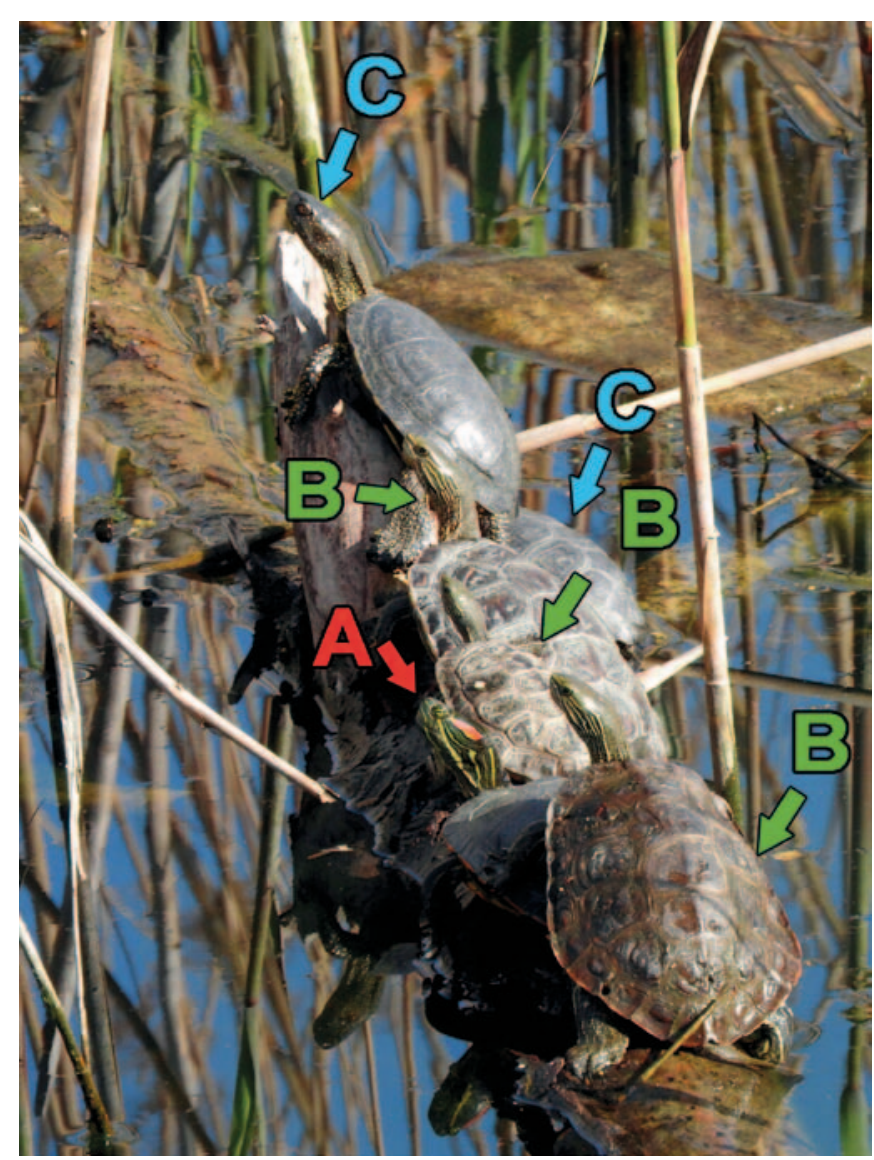

Figure 2. Turtles basking in the Anzali wetland $\mathbf{A}$. Red-eared slider (T. s. elegens), B. Caspian turtle (M. caspica), and C. European pond turtle (E. orbicularis)

During the 1990s, modern aquarium keeping became very popular in Iran and relied upon the importation of aquarium fish but also included red eared sliders. Many fish keepers bought these reptiles and kept them with their fish, most did not survive except for a few that grew large and started to consume the fish. Consequently, these turtles were released into the wild alongside two native pond turtle species: the Caspian turtle (Mauremys caspica) and European pond turtle (Emys orbicularis) (Mozaffari et al., 2016). The red eared slider is a generalist species occupying a broad ecological niche (Ernst \& Lovich, 2009) and is a potential competitor with the two native species for food and basking sites (Luiselli 
Table 1. Water bodies where T. s. elegans has been detected in Iran

\begin{tabular}{|c|c|c|c|c|}
\hline Locality & Grid reference & Description & $\begin{array}{l}\text { First } \\
\text { report }\end{array}$ & Authority \\
\hline $\begin{array}{l}\text { Amir-Kabir } \\
\text { reservoir }\end{array}$ & $35^{\circ} 58.2^{\prime} \mathrm{N}, 51^{\circ} 06^{\prime} \mathrm{E}$ & $\begin{array}{l}\text { Man-made reservoir for drinking water } \\
\text { and hydroelectric power }\end{array}$ & 2002 & Present authors \\
\hline $\begin{array}{l}\text { Sefidrud reservoir } \\
\text { (Manjil dam) }\end{array}$ & $36^{\circ} 44.7^{\prime} \mathrm{N}, 49^{\circ} 22^{\prime} \mathrm{E}$ & $\begin{array}{l}\text { Man-made reservoir for irrigation water } \\
\text { and hydroelectric power }\end{array}$ & 2005 & Present authors \\
\hline Shoormast Lake & $36^{\circ} 05.27^{\prime} \mathrm{N}, 53^{\circ} 02.8^{\prime} \mathrm{E}$ & Natural lake & 2012 & Moradi \& Rastegar-Pouyani, 2015 \\
\hline Mamloo reservoir & $35^{\circ} 36^{\prime} \mathrm{N}, 51^{\circ} 47.3^{\prime} \mathrm{E}$ & $\begin{array}{c}\text { Man-made reservoir - irrigation and } \\
\text { drinking water }\end{array}$ & 2015 & Safaei et al., 2015 \\
\hline $\begin{array}{l}\text { Eynak } \\
\text { wetland }\end{array}$ & $37^{\circ} 16.38^{\prime} \mathrm{N}, 49^{\circ} 32.5^{\prime} \mathrm{E}$ & $\begin{array}{l}\text { Four natural lagoons surrounded by } \\
\text { urban development }\end{array}$ & 2017 & Present authors \\
\hline Anzali wetland & $\begin{array}{l}37^{\circ} 22^{\prime} \text { to } 37^{\circ} 32^{\prime} \mathrm{N}, \\
49^{\circ} 14^{\prime} \text { to } 49^{\circ} 37^{\prime} \mathrm{E}\end{array}$ & Natural lake - shoreline agriculture & 2018 & Present authors \\
\hline
\end{tabular}

et al., 1997; Cadi \& Joly, 2004). How significant this might be for native turtle conservation in Iran is not clear, not least because in some locations the species may not be able to reproduce due to low temperatures or limited precipitation (Ficetola et al., 2009). This limitation could apply to AmirKabir, Mamloo and Sefidrud reservoirs that are located to the south of the Alborz mountains where there are long, cold winters. The very low numbers of $T$. s. elegans observed at these locations suggest that the species is not reproducing. Furthermore, although the Sefidrud reservoir connects to the Caspian sea via the Sefidrud river that crosses Boojagh national park, due to the length, water speed, and depth of reservoir it seems that there is little chance of turtles reaching Boojagh national park, alive.

Shoormast Lake, Eynak and Anzali wetlands are all located to the north of the Alborz mountains where winters are shorter and warmer. Although there is no record of successful reproduction in these habitats it does seem likely to occur because of both the large number of red eared sliders observed and the environmental similarity to sites with confirmed reproduction in Turkey (Çiçek \& Ayaz, 2015). But in the case of Shoormast Lake and Eynak wetland the threat to native species may be limited as they are effectively small isolated habitats not connected to river systems. They are also fully accessible so that it may be possible to eradicate the red eared sliders. In the Anzali wetland the situation is quite different. This is a vast area fed by rivers and canals and surrounded by agricultural land, especially rice farms, creating a significant dispersal corridor to other natural habitats along the southern side of the Caspian Sea. There are many places in and around the wetland that are inaccessible to people so that there is little prospect of eradication. However, we would urge all governmental and non-governmental organisations to take whatever action they can to limit the spread of $T$. scripta elegans in this wetland. There is also a need to address the fact that red eared sliders are still being imported into Iran. We think that banning such importation would be counterproductive since it would push the trade underground and make it even more difficult to control. Instead, we would recommend that current restrictions on keeping, selling, buying and captive breeding of the pond turtle Emys obicualris should be lifted. This species is plentiful in Iran and would be an ideal local substitute for $T$. s. elegans. This action combined with a comprehensive educational programme for pet keepers has the potential to limit future releases or escapes of red eared sliders.

\section{ACKNOWLEDGEMENTS}

We wish to thank the Iran Department of the Environment (DOE), and all DOE gourds especially Mr. Yoosof Rakhshe-bahar, who helped us during this study. We also wish to thank the Japan International Cooperation Agency (JICA) for facilitating this study.

\section{REFERENCES}

Cadi, A. \& Joly, P. (2004). Impact of the introduction of the red- eared slider (Trachemys scripta elegans) on survival rates of European pond turtle (Emys orbicularis). Biodiversity and Conservation 13: 2511-2518.

Chen, T.H. \& Lue, K.Y. (1998). Ecological notes on feral populations of Trachemys scripta elegans in northern Taiwan. Chelonian Conservation and Biology 3: 87-90.

Çiçek, K. \& Ayaz, D. (2015). Does the red-eared slider (Trachemys scripta elegans) breed in Turkey? Hyla 1: 4-10.

Ernst, C.H. \& Lovich, J.E. (2009). Turtles of the United States and Canada. Maryland, USA: Johns Hopkins University Press. $840 \mathrm{pp}$.

Ficetola, G. F., Thuiller, W. \& Padoa-Schioppa, E. (2009). From introduction to the establishment of alien species: Bioclimatic differences between presence and reproduction localities in the slider turtle. Diversity and Distributions 15: 108-116.

Feldman, M.L. (2007). The red-eared slider turtle (Trachemys scripta elegans) in New Zealand. Turtle and Tortoise Newsletter 10: 15-18.

Gasperetti, J., Stimson, A.F., Miller, J.D., Ross, J.P. \& Gasperetti, P.R. (1993). Turtles of Arabia. In Fauna of Saudi Arabia, Butticker W, Krupp F (eds). National Commission for Wildlife Conservation and Development: Riyadh and Pro Entomologia Basle 13: 170-367.

Gilan Regional Water Company. (2019). Sefidroud dam, URL: http://www.glrw.ir (accessed on December 1, 2019). 
Jarvis, P.J. (2000). Ecological Principles and Environmental Issues. UK: Prentice Hall. 320 pp.

Lowe, S., Browne, M., Boudjelas, S. \& De-poorter, M. (2000). 100 of the World's Worst Invasive Alien Species. A selection from the Global Invasive Species Database. The Invasive Species Specialist Group (ISSG) a specialist group of the Species Survival Commission (SSC) of the World Conservation Union (IUCN). 12 pp.

Luiselli, L., Capula, M., Capizzi, D., Filippi, E., Trujillo, J.V. \& Anibaldi, C. (1997). Problems for conservation of pond turtles (Emys orbicularis) in central Italy: is the introduced red- eared turtle (Trachemys scripta) a serious threat? Chelonian Conservation and Biology 2: 417-419.

Moradi, N. \& Rastegar-Pouyani, N. (2015). Biological aggression of the introduced red-eared slider, Trachemys scripta elegans (wied, 1939) (testudines: emydidae) in Iran. Russian Journal of Herpetology 22: 133-135.

Mozaffari, O., Kamali, K. \& Fahimi, H. (2016). Atlas of Reptiles of Iran. Tehran, Iran: Department of the Environment. 361 pp.
Mozaffari, O. (2018). A Field guide to Amphibians and Reptiles of Anzali wetland. Gilan, Iran: Anzali Wetland Ecological Management Project press.

Natividad, P., Carmen, D. \&, Judith, H. (2008). The reproductive ecology of exotic Trachemys scripta elegans in an invaded area of southern Europe. Aquatic Conservation: Marine and Freshwater Ecosystems 18: 1302-1310.

Newberry, R. (1984). The American red-eared terrapin in South Africa. African Wildlife 38: 186-189.

Safaei, B., Ghaffari, H., Fahimi, H., Broomand, S., Yazdanian, M., Najafi, E., Kazemi, M. (2015). The Herpetofauna of Iran: checklist of taxonomy, distribution and conservation status. Asian Herpetological Research 6: 257-290.

Accepted: 27 March 2020 